\title{
AN APPLICATION OF XYZ ANALYSIS IN COMPANY STOCK MANAGEMENT
}

\begin{abstract}
Keeping inventory is often a prerequisite for the functioning of the production and commercial companies as well as multiple service providers. The level of inventories, as well as charges depends on sales - but the charges are the result of sales (charges are the result of sales, while sales volume is also dependent on debt management strategies), and the stocks precede the sales; they are one of the conditions. The stocks should be adjusted to the expected sales. In the article there have been presented the $\mathrm{ABC}$ and $\mathrm{XYZ}$ analyses in the application of inventory management exemplified by an office stationery company. The $\mathrm{ABC}$ analysis for inventory shows that a relatively small number of items and the storage unit are the most important or predominant part in all of their value. The classification system allows to include the stored position into three groups according to the relative importance or value of the items making up the group. The XYZ analysis shows the differences between the goods in stocks and the used ones. The $\mathrm{Z}$ elements are used in a very irregular way and therefore, the size of the supply is unpredictable. For those parts there should be chosen a good supplier where the delivery time is short, so as to be able to rely on small batches of fast deliveries just in time.
\end{abstract}

Keywords: XYZ analysis, management, storage management

\section{INTRODUCTION}

One way to increase the market attractiveness of a company is to improve the functioning of processes (including storage). A continuous cost reduction and process acceleration requires changes in the organization of the warehouse. The activity of the management responsible for material storage has a significant impact on the functioning of the entire logistics system of a company. Decisions made in the area of material supply responsible for the logistics processes will have a direct impact on the level of services offered to a customer, the company's ability to compete with other companies and the level of sales and profits on the market. In such a situation it is necessary to plan the supply in time.

Warehouse management and related with it inventory control have always been of a great interest of the management of companies that have their own warehouses. This is mainly connected with the freezing of a large part of the working capital, precise determination of safety stock and the economic size of the order. Keeping inventory is often a prerequisite for the functioning of the production and commercial companies as well as the multiple service providers. In the production companies the inventories of raw materials are necessary to maintain the continuity of production, while the production inventory created during the production process and inventory of finished products and goods (commercial companies) allow to meet the needs of customers. The stock, just as the

\footnotetext{
${ }^{1} \mathrm{PhD}$ Irena Nowotyńska, Department of Computer Engineering in Management, Rzeszow University of Technology, Rzeszow, al. Powstańców Warszawy 8, 35-959 Rzeszów, tel. 17 8651894, e-mail: i_nowot@prz.edu.pl.
} 
charges depend on sales - but the charges are the result of sales (sales at the same time also depend on debt management strategies), and the stock precedes the sales, it is one of its conditions.

The level of inventories should be adapted to the expected sales. Many companies can realize sales only in a situation when they have a supply of finished products or goods (e.g traditional traders, putting them in shops or markets). There are also companies that, at the time of offering specific products to potential customers, do not have them physically. This applies, for example, to the order production or e-commerce. However, even in these cases it is difficult to avoid such stocks e.g. because of the production in progress (in the first case) or the goods (in the second case - even if the orders are realized within 24 hours). Keeping inventory in a company costs, but also it has its positive aspects. Thus, in practice, in production and trade enterprises the elimination of stocks seems neither possible nor beneficial (stocks may not be present in some of the service companies). Without doubt, however, it is necessary to increase the efficiency of their management, especially that the errors in inventory management can lead to a decline sales or inflating costs, which can have negative effects on the company performance [6].

The logistics activity of a company requires gathering and organizing information about the movement of goods and services. When the stocks of goods are very numerous then the cognitive classifications are necessary. Companies often miss a simple inventory management mechanisms. Sometimes some companies use the simplest method of managing material stock, and thus limiting them in a maximum way. The volume of production is calculated (by value) and it is then decided, for what level of inventory a company can afford. Often, companies need to work so as with the least possible freezing money (i.e. having the least amount of inventory) they could ensure regular production and that always the required material was at the disposal of the production, as even the smallest purchase of raw material may stop the entire production process, leading to downtime. On the other hand, the accumulation of too many materials could expose the company to the loss of liquidity. The problems associated with the management of inventory can be solved through the use of purchasing policy by ABC / XYZ method.

\section{ABC ANALYSIS}

$\mathrm{ABC}$ method was formulated while doing the research on income concentration in the capitalist countries at the turn of the nineteenth and twentieth centuries. The ABC analysis is conducted in order to obtain the appropriate classification and assignment of products or materials from a set to one of three groups distinguished for production planning, purchasing and warehouse management. The criterion, according to which the classification is done, can create, expressed in various measures, the size of production, demand and sales during the period. As for the stocks it means that a relatively small number of items or the storage unit is of the greatest importance or predominant share of the total values. The classification system allows to include the stored position into three groups according to the relative importance or value of the items making up the group. The division into groups is determined by the share ratio. The A group is of $80 \%$ of the total value of the volume which determines the division, $\mathrm{B}$ of $15 \%$ and $\mathrm{C}$ of $5 \%$. It may be surprising that the usually group A, which generates the vast majority of the analyzed traits is usually a small percentage of the population in respect to all the items. This phenomenon is called the rule of $80 / 20$ and it is according to the Pareto principle, upon which the ABC analysis 
it is based [9]. The error which often appears during the $\mathrm{ABC}$ analysis results in paying much attention to the products of group A and disregarding or suppressing the items from groups $\mathrm{B}$ and $\mathrm{C}$ as less important. However, if all the attention of the company management is focused on the position of group A, the items from B and C groups may be less available Some companies have a policy to maintain stocks using the $A B C$ method based on differentiating their availability. Then the items from the A group are available immediately or through periodic logistics services, and positions of groups B and C, if they are in sales, are available when they are needed. One should, therefore, remember that the $\mathrm{ABC}$ analysis does not divide the materials or products into important, less important and unimportant ones. Often, in the group $\mathrm{C}$ can be found apparently an unnecessary product which is necessary to assembly the finished product. It may also be like this that the items of group $\mathrm{C}$ are some new products that have the potential to sell well, or they are very profitable items, even though their share of sales is small. Figure 1 shows the distribution of the total value of the material stocks of the company with the application of the $\mathrm{ABC}$ method using the Lorenz curve [4]. On the X axis there is placed the number of items as a percentage but on the $\mathrm{Y}$ axis it is placed the corresponding cumulative percentage of the production, demand or sales volume related to their total value.

Fig. 1. Visualization of $\mathrm{ABC}$ analysis results by using the Lorenz curve

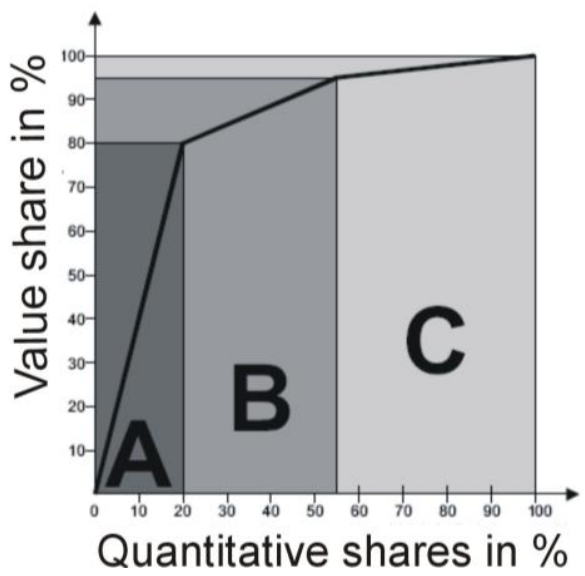

Source: [4]

- General benefits of the $\mathrm{ABC}$ analysis:

- Increasing the level of control over inventory

- Increase in turnover

- Increase in the level of customer service

- Increase in profit

- Optimizing the use of storage space

- Improvement of work efficiency. 
The versatility of the method lies in the fact that its implementation does not require complex tools and high workload. The analysis can be performed using the most simple spreadsheet which is, e.g. MS EXCEL.

\section{ABC ANALYSIS IN INVENTORY MANAGEMENT}

The ABC analysis was carried out for commercial and wholesale company dealing with the sales of office stationery. At the first stage there were calculated the material costs of the items on the basis of the necessary quantities and unit prices, and then they were ranked. Next, it was made an arrangement of product items in accordance with the obtained ranking and the cumulative relative error (in \%) of quantity and value consumption was calculated. On the basis of the cumulative values it is then carried out an assignment of different materials into one of three classes (Table 1).

Table 1. The final form of $\mathrm{ABC}$ analysis

\begin{tabular}{|c|c|c|c|c|c|c|c|}
\hline & Product name & $\begin{array}{c}\text { Quantitive } \\
\text { consumption }\end{array}$ & Unit price & $\begin{array}{c}\text { The volue } \\
\text { of } \\
\text { consumption }\end{array}$ & $\begin{array}{c}\text { \%share of } \\
\text { value of } \\
\text { consumption }\end{array}$ & $\begin{array}{c}\text { The cumulative } \\
\text { value of } \\
\text { consumption }\end{array}$ & Class \\
\hline $\mathbf{1}$ & Foil to binding machine $0,15 \mathrm{~mm}$ & 654 & 13,4 & 8763,6 & $\mathbf{2 3 , 4 5}$ & $\mathbf{2 3 , 4 4}$ & $\overline{\mathbf{A}}$ \\
\hline 2 & Plastic workbook A4 black & 1934 & 3,05 & 5898,7 & 15,78 & 39,22 & $\mathbf{A}$ \\
\hline 3 & Blue marker & 2141 & 2,09 & 4474,69 & 11,97 & 51,19 & $\mathbf{A}$ \\
\hline 4 & Office block A4 & 1769 & 1,92 & 3396,48 & 9,09 & 60,27 & $\mathbf{A}$ \\
\hline 5 & Ballpen BK77 blue & 11786 & 0,26 & 3064,36 & 8,20 & 68,46 & $\mathbf{A}$ \\
\hline 6 & Crystal shirt A4 & 412 & 6,18 & 2546,16 & 6,81 & 75,27 & $\mathbf{A}$ \\
\hline 7 & Briefcase with elastic red & 2633 & 0,92 & 2422,36 & 6,48 & 81,75 & B \\
\hline 8 & Shirt for CD & 973 & 2,38 & 2315,74 & 6,20 & 87,94 & B \\
\hline $\mathbf{9}$ & Office block A5 & 2168 & 1,03 & 2233,04 & 5,97 & 93,91 & B \\
\hline 10 & Briefcase with elastic black & 1850 & 0,92 & 1702 & 4,55 & 98,46 & $C$ \\
\hline 11 & Ballpen PIK 011 blue & 1047 & 0,51 & 533,97 & 1,43 & 99,58 & C \\
\hline 12 & Briefcase with elastic A4 blue & 30 & 0,92 & 27,6 & 0,07 & 100 & C \\
\hline
\end{tabular}

Source: own research

The $\mathrm{ABC}$ analysis is very helpful in selecting from the whole range group the products with a large range of sale or consumption. This is extremely important from the point of view of stocks management, as they will also have a high value. A purely rational circumstances point at the desirability of use "sharp regime" in relation to the products of group A, while for the other products there can be used much more liberal rules for ordering. Typically, in these latter position of the products there are formed large stocks (halfyearly or even yearly), which allows for the extension of the control ranges of their supply logistics processes, and thus the concentration of effort and attention to critical items for business logistics costs (due to the need to freeze working capital, the multitude and variety of warehouse parties). The nature of the market and the state of the balance between supply and demand allow for the implementation of purchases depending on the needs. This allows not to keep stocks, and thus reduce the total costs of the supply.

Recommendations for two extreme groups of products. Recommendations for Class A materials:

- continuous inventory control, 
- careful planning of stock of safety and information states,

- very accurate setting of the supply,

- orders in accordance with the actual needs,

- timeliness of delivery,

- careful selection of suppliers.

Recommendations for Class C materials:

- identification of the needs based on simple methods of forecasting,

- simplified ordering process,

- random check of stock levels,

- large volume of orders,

- high states of stock of safety.

The carried out division, however, is not sufficient for making decisions such as the maintenance of inventory levels of individual products, since the two different products can be found in group A for entirely different reasons. The second, in addition to the value, criterion of the division of materials or products should be the size of quantitative sales. The division according to this criterion is called the XYZ division.

\section{XYZ ANALYSIS}

The $\mathrm{XYZ}$ analysis is a special dynamic extension of the static $\mathrm{ABC}$ analysis [1-2,7]. The results of the analysis allow to divide the stocks into groups in terms of prediction accuracy and / or regularity of the demand / need for specific material groups. In the XYZ analysis there are three groups of materials that can be described as follows:

- X material group has a fixed size of demand / need, and it is characterized by small periodic fluctuations, which provides high accuracy of forecasting,

- Y material group has moderate fluctuations in demand / need, which allows for an average accuracy of forecasting,

- Z material group has irregular demand / need, which allows for low accuracy of forecasting [9].

The designated material groups $\mathrm{X}, \mathrm{Y}$ and $\mathrm{Z}$ allow to take an appropriate decision while calculating the size of the order, which is extremely important for products with short product life cycle. Precise determination of the phase of the product life cycle (distinguished by five stages: introduction, growth intensity of sales, product maturity, market saturation and a decrease in sales), will eliminate the risk of retention of large quantities of products in stock, and thus reduce the problems resulting from return or destruction of products that have not been sold [3].

The XYZ analysis consists of three basic stages:

- determination of the demand scattering coefficient for individual products,

- sorting the materials by increasing the scattering coefficient,

- graphical presentation of the results by class X, Y,Z.

The first stage involves the determination of the scattering coefficient. In order to calculate the coefficient one needs to have the arithmetic mean which is the ratio of the global value of the studied characteristics against the population size. The arithmetic mean in the detailed series for the general $\mathrm{N}$-element population is calculated as: 


$$
\bar{x}=\frac{\sum_{i=1}^{n} x_{i}}{N}
$$

where:

$\mathrm{xi}$ - characteristics feature in i time, for $\mathrm{i}=1,2, \ldots, \mathrm{n}$;

$\mathrm{N}$-number of general population.

The arithmetic mean is a resultant of the characteristics value for all units of the population, it is also the most common characteristics to present the average level of the characteristics. The next step is to determine the standard deviation $\mathrm{s}$ (x). The standard deviation is calculated as the square root of the variance (for the general population) which is the arithmetic mean of the squared deviations of the characteristics value from the mean value.

$$
s(x)=\sqrt{s^{2}}(x)=\sqrt{\frac{\sum_{i=1}^{n}\left(x_{i}-\overline{x)^{2}}\right.}{N}}
$$

where:

$\mathrm{xi}$ - characteristics value in i period, for $\mathrm{i}=1,2, \ldots, \mathrm{n}$;

$\bar{x}$ - arithmetic mean;

$\mathrm{N}$ - number of general population.

The standard deviation measures the average variation of the characteristics value around the arithmetic mean. The last element which requires the calculations is the demand scattering coefficient $\left(\chi_{z}\right)$, which is calculated by using the formula:

$$
\chi_{z}=\frac{s(x)}{\bar{x}}
$$

where:

$\bar{x}$ - arithmetic mean;

$\mathrm{s}(\mathrm{x})$ - standard deviation of population.

The next stages of the proceeding is to sort from the smallest to the largest, and the division into material groups. It is assumed the following division:

- the items of the $\mathrm{X} \in$ group $[0 \%, 10 \%]$, and they are the products of high accuracy of prediction,

- the items of the $\mathrm{Y} \in$ group $[10 \%, 25 \%]$, and they are the products of the average accuracy of prediction,

- the items of the $Z \in$ group $[25 \%, \infty]$ and they are the products of the low accuracy of prediction.

It is important to note that the quoted ranges are just agreed ones and depending on the specificity of a company or industry, they can be easily controlled. However, the application of the principle remains the same. To know of the group to which the range belongs is 
very important information for the rational control of the logistics supply processes. This makes it possible to plan optimal, due to the total cost of supply, policy of orders.

After determining the material groups one can adopt the appropriate strategy while ordering the products. While analyzing the results of the XYZ and the earlier ABC analysis in the company there can be assumed the proper deterministic or stochastic methods for determining the demand [5].

\section{XYZ ANALYSIS IN STOCK MANAGEMENT}

The object of an analysis is a trading company - wholesale, which sells stationery products. The company, in order to ensure continuity of supply to its customers has its own warehouse. For the research there was adopted the group of 15 items and information about their sales from the last 27 months. When starting the XYZ analysis there was properly prepared input data in a table form and made appropriate calculations (arithmetic mean, standard deviation, demand scattering coefficient $\chi_{\mathrm{z}}$, , the XYZ group). The determination of the XYZ analysis aims at better control of the executed orders, increasing profitability, and thus bringing benefits in the form of smaller losses resulting from residual products in stock. The division into the XYZ item groups and a part of the table with the input data is shown in Table 2.

In the analysed case the most of the items were in $\mathrm{Z}$ group (demand occurring sporadically). The items classified as a $\mathrm{Z}$ group have very irregular demand and low accuracy of its predictions.

Table 2. The division into groups with material XYZ data table portion

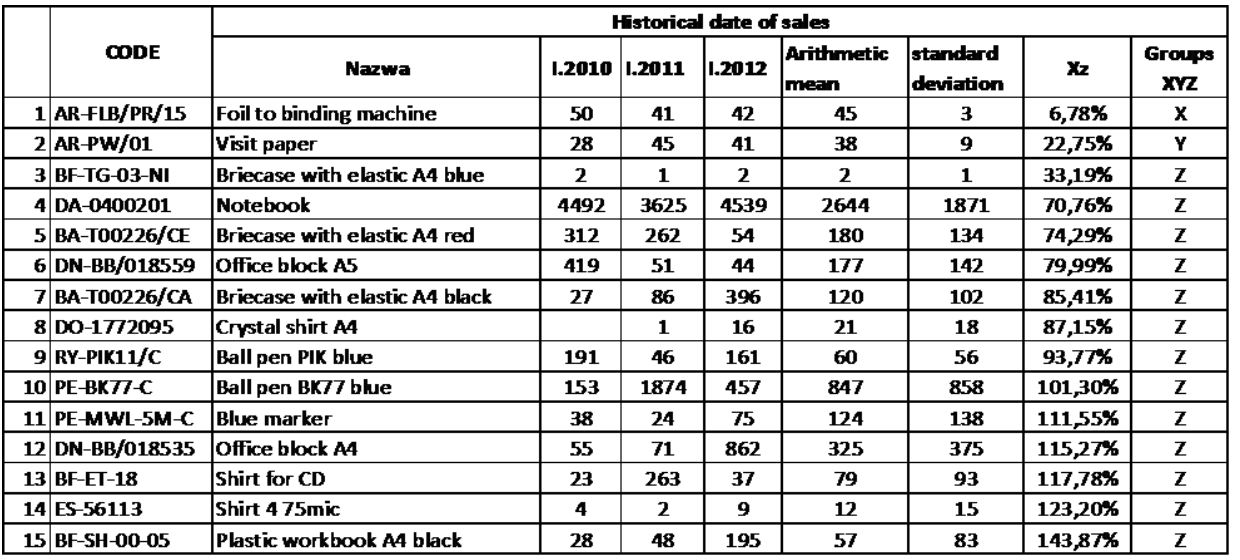

Source: Own calculations based on data generated from the accounting system of firm.

The analysis results of the relevant item groups do not allow clearly to answer the question, what decision should be taken while ordering a new batch of the article, and they are only a guideline for further actions. In order to make a decision, one can use the graphical development which results in generating projected trend line that can determine what course of action should be potentially taken in order the goods do not stack up in the warehouse, and on the other hand, the potential customer does not have to wait for the product (Fig. 2, Fig. 3). 
Fig. 2. Consumption / sale of an article with the line projected trend line (from 24 months)

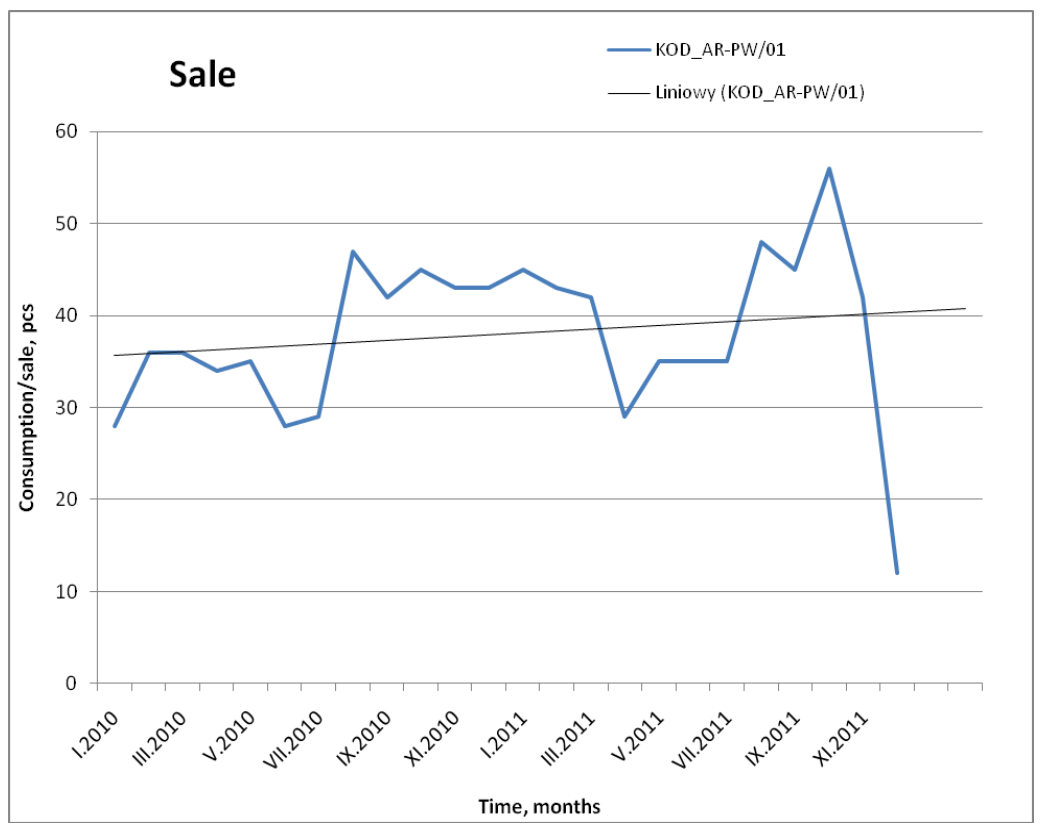

Source: Own calculations

Fig. 3. Consumption / sale of an article with the line projected trend line (from 3 months)

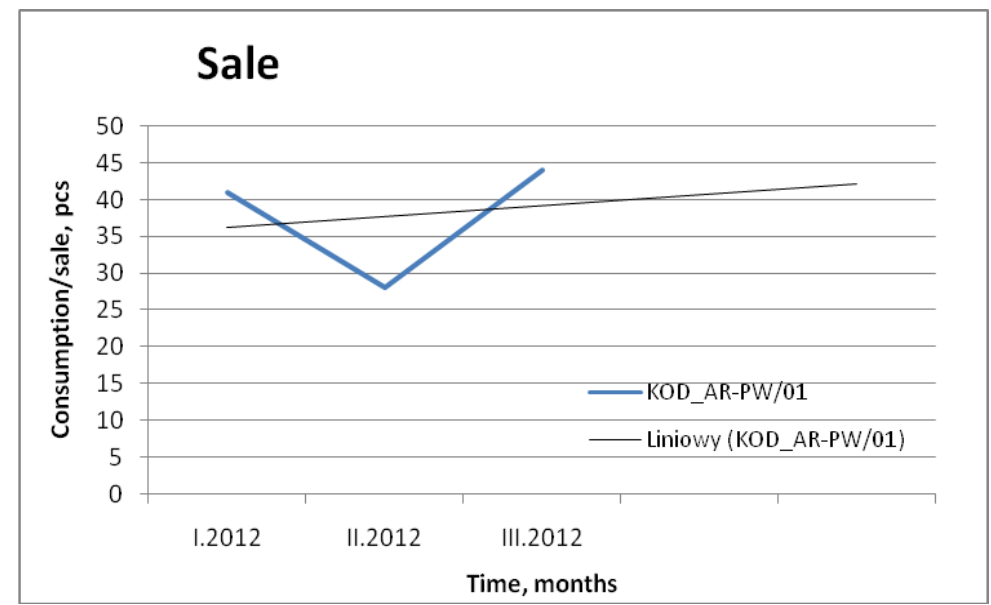

Source: Own calculations

The use of long-term trend line allows to see if there is a chance for long-term sales growth, and thus to determine the level of inventory in the warehouse. In the analyzed example, it can be concluded that the order should be maintained at a constant level, how- 
ever, it should strive to minimize the inventory in the store because it is unknown if the phase of demand decline for the article in the short term is not the first sign of a lack of interest from buyers in this article, which may mean that the article is in the phase of the sales drop in its life cycle.

\section{CONCLUSIONS}

The results of the $\mathrm{ABC}$ analysis allow to plan precisely the actions aiming at an increase of global incomes from sales. The analysis of sales income by characteristics gives a deeper understanding of the structure of sales of not only individual products, but also a specific batch of a single product. If the method is used to deploy inventories, the access to the more common goods should be easier than to those less rotating. However, one should keep in mind the strategic products of group A, which may rotate slightly, but have a large share of the value.

The XYZ analysis shows the differences between the goods in stocks and the used one. The $\mathrm{Z}$ elements are used in a very irregular way and, therefore, the size of the supply is unpredictable. For those parts there should be chosen a good supplier for whom the delivery time is short, in order to be able to rely on small batches of fast deliveries on time.

If the analysis is included by XYZ realm of supply as a tool to support decision making, then on its basis it may be appropriate to develop a system of synchronized supply with production processes for the items classified to the $\mathrm{X}$ group, and for the $\mathrm{Y}$ group the supply system with the task of setting up a certain level of inventory, whereas for the $\mathrm{Z}$ group the systems compliant with irregular supply needs. An important feature of the materials in the $\mathrm{XYZ}$ analysis is the accuracy of predicting the level of their demand (the consumption) [8].

\section{REFERENCES}

[1] Abt S., Zarzqdzanie logistyczne w przedsiębiorstwie Polskie Wydawnictwo Ekonomiczne, Warszawa 1998

[2] Gołembska E., Podstawy logistyki Wydawnictwo Naukowe Wyższej Szkoły Kupieckiej,Łódź 2006

[3] http://zbc.uz.zgora.pl/Content/8527/Rozdział\%202.2.pdf

[4] http://aneksy.pwn.pl/zarzadzanie/?id=414\&typ=stud

[5] Korzeń Z., Logistyczne systemy transportu bliskiego i magazynowania, Tom II, Biblioteka Logistyka, ILiM, Poznań 1999.

[6] Mantura W. (red.), Marketing przedsiębiorstw przemysłowych, Wydawnictwo Politechniki Poznańskiej, Poznań 2000.

[7] Niziński S., Logistyka Wydawnictwo ART, Olsztyn 1999

[8] Szymczak M.: Decyzje logistyczne z Excelem, Wydawnictwo Difin, Warszawa 2011

[9] Vollmuth H. J., Controlling, Agencja Wydawnicza Placet, Warszawa, 1995

\section{ZASTOSOWANIE ANALIZY XYZ W GOSPODAROWANIU ZAPASAMI FIRMY}

Utrzymywanie zapasów jest bardzo często nieodzownym warunkiem funkcjonowania przedsiębiorstw produkcyjnych, handlowych i wielu przedsiębiorstw usługowych. Poziom zapasów, podobnie jak należności, uzależniony jest od sprzedaży - z tym, że należności powstają w wyniku sprzedaży (należności są efektem sprzedaży, jednocześnie wielkość sprzedaży jest również uzależniona 
od strategii zarządzania należnościami), a zapasy tę sprzedaż poprzedzają, są jednym z jej warunków. Wielkość zapasów powinna być dostosowana do przewidywanej sprzedaży. W artykule przedstawiono analize $\mathrm{ABC}$ i XYZ w zastosowaniu w gospodarce zapasami na przykładzie firmy zajmującej się sprzedażą artykułów biurowych. Analiza $\mathrm{ABC}$ w odniesieniu do zapasów pokazuje, że stosunkowo niewielka liczba pozycji lub jednostek składowania ma największe znaczenie lub przeważający udział w całej ich wartości. System klasyfikacji pozwala na zaliczenie składowanych pozycji do trzech grup według względnego znaczenia lub wartości pozycji tworzących daną grupę. Analiza XYZ pokazuje różnice między towarem magazynowanym a wykorzystywanym. Elementy $\mathrm{Z}$ są używane bardzo nieregularnie i dlatego wielkość ich dostaw jest trudna do przewidzenia. Dla tych części powinno się wybrać dobrego dostawce, u którego czas dostawy jest krótki, tak by móc liczyć na niewielkie partie szybkich dostaw dokładnie na czas.

Słowa kluczowe: analiza XYZ, zarządzanie, gospodarka magazynowa.

DOI: $10.7862 /$ rz.2013.mmr.7

Teks złożono w redakcji: styczeń 2013

Przyjęto do druku: czerwiec 2013 